\title{
Pigeon (Columba L.) meat iron solubility and availability for absorption in rats
}

\author{
BY G. O. LATUNDE-DADA AND R. J. NEALE* \\ Department of Applied Biochemistry and Food Science, \\ University of Nottingham, School of Agriculture, \\ Sutton Bonington, Loughborough, Leics LE12 5RD
}

(Received 25 February 1985 - Accepted 10 October 1985)

1. The distribution of iron in ${ }^{59} \mathrm{Fe}$-labelled pigeon (Columba L.) leg and breast muscle and liver were determined by gel filtration. While the insoluble Fe was between 14 and $25 \%$ of the total Fe from the tissues, the haem-Fe represented $79 \cdot 1 \%$ (breast) to $45 \%$ (liver) of the total $\mathrm{Fe}$ and ferritin was between $5.5 \%$ (breast) and $26.5 \%$ (liver) of the total Fe.

2. The tissue haem-Fe concentration was found to be lower than that determined by gel filtration using the method of Schricker et al. (1982) for non-haem-Fe and obtaining haem-Fe by difference.

3. A simulated in vitro digestion procedure showed significantly $(P<0.01)$ reduced ${ }^{59} \mathrm{Fe}$ solubility from ${ }^{59} \mathrm{Fe}-$ labelled pigeon meat after cooking at $90^{\circ}$ for $30 \mathrm{~min}$.

4. ${ }^{59} \mathrm{Fe}$ absorption from whole pigeon meat and soluble extract was significantly reduced by cooking when given to Fe-replete rats. Cooking liver, however, slightly improved ${ }^{5 \theta} \mathrm{Fe}$ absorption in Fe-replete rats.

5 . ${ }^{59} \mathrm{Fe}$ absorption from the separated pigeon-meat fractions (haemoproteins, ferritin and haemosiderin) was variable but considerably lower than that from whole meat.

6. The relative distribution of $\mathrm{Fe}$ compounds in meat, the processing conditions they are subjected to and the protein content and composition may all influence the absorption of meat-Fe to some degree.

The importance of meat in iron nutrition is widely recognized (Monsen et al. 1978; Bjorn-Rasmussen \& Hallberg, 1979). The presence in meat of haem compounds, which are highly available for absorption, and their enhancing effect in non-haem-Fe absorption is of practical significance in the daily recommended dietary intake of Fe (Food and Agriculture Organization/World Health Organization, 1970). Considerable research has provided information on the absorption and availability of $\mathrm{Fe}$ from meat and meat fractions (Martinez-Torres \& Layrisse, 1971; Martinez-Torres et al. 1976; Bogunjoko et al. 1983); however, the exact mechanism or the form of meat-Fe absorption and the 'meat effect' on non-haem-Fe absorption are still unresolved (Conrad et al. 1967; Hazell et al. 1978).

The amount and distribution of Fe compounds vary in different meats (Clement et al. 1972; Hazell et al. 1978; Hazell, 1982) and this could influence the absorption and availability of meat-Fe. Also, quite recently, Bogunjoko et al. (1983) showed that cooking markedly reduced Fe absorption from chicken meat and this is thought to be due to the denaturation and polymerization of some of the haemoproteins. The present work extends earlier studies with chicken meat and describes Fe absorption from pigeon (Columba L.) meat, which contains significantly higher amounts of haemoproteins than chicken meat.

MATERIALS AND METHODS

Preparation of ${ }^{59} \mathrm{Fe}$-labelled pigeon meat

The Fe compounds of pigeon muscle were labelled with ${ }^{59} \mathrm{Fe}$ by intraperitoneal injection of about $1 \mathrm{ml}$ of a solution containing approximately $80 \mu \mathrm{Ci}{ }^{59} \mathrm{Fe}$-labelled ferric citrate

\footnotetext{
* For reprints.
} 
(14 $\mu \mathrm{g} \mathrm{Fe} / \mathrm{ml}$; Amersham International, Amersham, Bucks) into six immature 6-month-old pigeons. The pigeons were maintained on a ration composed of mixed whole cereal and field beans (Vicia faba) for 4 weeks. This allowed uniform labelling of all Fe pools. The birds were killed by cervical dislocation and bleeding, and ${ }^{59} \mathrm{Fe}$-labelled breast, leg and liver tissues were stored separately at $-20^{\circ}$ until needed.

\section{Chemical and radioactive analysis}

The concentration of ${ }^{59} \mathrm{Fe}$ in the whole meat was determined by weighing $1 \mathrm{~g}$ into counting vials and determining its radioactivity by duplicate counting in a well-type sodium iodide crystal gamma assay scintillation counter and scaler timer (Nuclear Enterprises Ltd, Sighthill, Edinburgh). Extracts or solutions were also counted in a similar manner, keeping the volume constant. Chemical Fe contents were measured by atomic absorption spectrophotometry (EEL 240) after dry ashing of the meat samples as described previously (Bogunjoko et al. 1983).

\section{Distribution of Fe in pigeon muscle and liver}

Known weights of tissues were cut into small pieces and homogenized using an MSE homogenizer with stainless-steel blades, in five times their weight of $0.1 \mathrm{M}$-potassium orthophosphate buffer for $1 \mathrm{~min}$. The slurry obtained was transferred into $250-\mathrm{ml}$ polyethylene centrifuge-tubes and centrifuged at $11000 \mathrm{~g}$ and $0^{\circ}$ for $30 \mathrm{~min}$. After decanting the supernatant fraction, the residue was re-homogenized with buffer and centrifuged under the same conditions. The extraction was done three times. The pooled supernatant fractions were then concentrated by rotary vacuum evaporation at a temperature no higher than $30^{\circ}$ before subsequent analysis. Soluble Fe compounds in the concentrated supernatant fraction were fractionated on Sephacryl S-300 (column height $490 \mathrm{~mm}$, bed volume $240 \mathrm{ml}$, flow rate $20 \mathrm{ml} / \mathrm{h}$; Sigma Chemical Co., Poole, Dorset). The columns were equilibrated and eluted with $0 \cdot 1 \mathrm{M}$-potassium orthophosphate buffer, $\mathrm{pH}$ 7. Fractions $(5 \mathrm{ml})$ were collected and analysed for ${ }^{59} \mathrm{Fe}$, protein $(280 \mathrm{~nm})$ and haemoprotein $(410 \mathrm{~nm})$. The column was calibrated with ferritin, bovine serum albumin, myoglobin and cytochrome $c$.

\section{Haem- and non-haem-Fe determinations of pigeon muscle}

Non-haem-Fe was determined in pigeon tissues by the method described by Schricker $e t$ al. (1982). Meat samples ( $5 \mathrm{~g}$ ) were incubated in $15 \mathrm{ml}$ of an acid mixture consisting of equal volumes of $6 \mathrm{M}$-hydrochloric acid and trichloroacetic acid (TCA; $400 \mathrm{~g} / \mathrm{l}$ ) at $65^{\circ}$ for $20 \mathrm{~h}$ in loosely-stoppered tubes. Of this solution, $1 \mathrm{ml}$ was pipetted into a test-tube and $5 \mathrm{ml}$ of the colour reagent (see below) was added and mixed thoroughly. The absorbance was read at $540 \mathrm{~nm}$ after $10 \mathrm{~min}$. Standard solutions of ferric chloride were treated in the same manner. The colour reagent was made by mixing together $20 \mathrm{ml}$ saturated sodium acetate and $1 \mathrm{ml}$ bathophenanthroline reagent. The latter solution consisted of $0.162 \mathrm{~g}$ sulphonated bathophenanthroline dissolved in distilled water plus $1 \mathrm{ml} 1 \mathrm{M}$-thioglycolic acid and the solution made up to $100 \mathrm{ml}$. Haem-Fe was calculated as the difference between the total and non-haem-Fe in the meat samples.

\section{In vitro digestion procedure}

A pigeon meat sample $(10 \mathrm{~g})$ was homogenized with $100 \mathrm{ml} 0.1 \mathrm{M}-\mathrm{HCl}$ in an MSE homogenizer with stainless-steel blades. It was assumed that no Fe contamination resulted from this procedure although no checks were made. The $\mathrm{pH}$ of the slurry was adjusted to 1.5 with concentrated $\mathrm{HCl}$, and $50 \mathrm{mg}$ pepsin (EC 3.4.23.1; activity 1750 units/mg protein; Sigma Chemical Co.) were added. It was then incubated at $37^{\circ}$ for $1.5 \mathrm{~h}$ with continuous stirring. Duplicate $5 \mathrm{ml}$ samples were taken and the $\mathrm{pH}$ was adjusted to 7 by 
gradual addition of solid sodium bicarbonate (Fisons Chemical Co., Loughborough, Leics) and constant stirring. Further $5.0 \mathrm{ml}$ duplicate samples were taken after this neutralization procedure. Pancreatin-bile extract $(5 \mathrm{ml} ; 4 \mathrm{~g}$ pancreatin; Organon) and $25 \mathrm{~g}$ bile extract (porcine dispersed in 1 litre $0.1 \mathrm{M}$-sodium bicarbonate; Sigma Chemical Co.) were added to the digestion medium and the $\mathrm{pH}$ was maintained at 7 by the $\mathrm{pH}$-stat equipment (Radiometer, Copenhagen). This usually involved the addition of variable quantities of $0 \cdot 1 \mathrm{M}-\mathrm{HCl}$ to counter a rise in $\mathrm{pH}$ resulting from digestion. The digests at the different digestion stages were centrifuged at $8000 \mathrm{~g}$ and the supernatant fractions analysed for ${ }^{59} \mathrm{Fe}$ activity by duplicate counting in the gamma counter.

\section{In vivo absorption of ${ }^{59} \mathrm{Fe}$}

Fe-replete male Wistar rats weighing about $250 \mathrm{~g}$ and caged in groups of four were used in the present study. Laboratory chow (Fe content $309 \mathrm{mg} / \mathrm{kg}$ ) was removed from the animals overnight and the following morning 5-ml portions of pigeon test meals (prepared as described by Bogunjoko et al. (1983)) were given intra-gastrically by oral intubation. Rats were killed by a sharp blow on the head and cervical dislocation at 120 min after dosing. The abdominal cavity was opened and ligatures were placed at the gastro-oesophageal and ileo-caecal positions. Segments of the gastrointestinal tract and their contents were estimated for ${ }^{59} \mathrm{Fe}$ activity by removing the stomach, small intestine and colon and carefully washing out the contents into 5 -ml counting vials. The remaining gut segments were counted in 5-ml counting vials. ${ }^{59} \mathrm{Fe}$ absorption was calculated as the difference between the ${ }^{59} \mathrm{Fe}$ activity administered and the ${ }^{59} \mathrm{Fe}$ activity recovered in the gut wall and gut contents.

\section{Composition of test meals}

Based on the total $\mathrm{Fe}$ determinations of labelled pigeon tissues, test meals containing $8 \mu \mathrm{g} \mathrm{Fe} / \mathrm{ml}$ were prepared as follows: (1) raw whole meat slurry was prepared by homogenizing a known weight of whole pigeon breast meat in distilled water; (2) cooked whole pigeon meat was obtained by heating a known weight of pigeon meat in distilled water at $90^{\circ}$ for $30 \mathrm{~min}$ and then homogenizing; (3) raw pigeon meat soluble extract was prepared by homogenizing a known weight of pigeon meat in distilled water and centrifuging the slurry at $8000 \mathrm{~g}$ for $15 \mathrm{~min}$; (4) cooked pigeon meat extract was prepared by heating the soluble extract obtained as for test meal 3 to $90^{\circ}$ for 30 min and rehomogenizing; (5) raw pigeon insoluble residue was prepared by the same extraction procedure as in test meal 3 and a known weight of the insoluble residue was re-homogenized in distilled water; (6) cooked pigeon insoluble residue was prepared by cooking the weighed extracted residue (test meal 3) in distilled water for $30 \mathrm{~min}$ at $90^{\circ}$ followed by homogenization; (7) pigeon meat haemoproteins were prepared by following the extraction procedure as for test meal 3; the soluble extract was heated in a water bath at $90^{\circ}$ for $30 \mathrm{~min}$ to precipitate the haemoproteins and, after cooking, the heat coagulum (haemoproteins) was rehomogenized in distilled water at the correct $\mathrm{Fe}$ level; (8) muscle ferritin was assumed to be present in the supernatant fraction after the heat precipitation of the haemoproteins from the soluble extract. The low-molecular-weight $\mathrm{Fe}$ compounds were removed from this solution by dialysis against ten times its volume of distilled water with stirring for $72 \mathrm{~h}$ at $3^{\circ}$, water being changed every $2 \mathrm{~h}$; the retentate was regarded as ferritin; ( 9 and 10) raw and cooked liver meals were prepared in the same way as for test meals 1 and 2 for pigeon whole meat.

\section{Statistics}

Statistical analysis of in vitro and in vivo results were performed using the Student's $t$ test and $P$ values $<0.05$ were considered to be significant. 
Table 1. Chemical and radioactive iron contents of pigeon (Columba L.)
tissues (wet weight)

(Values are means with their standard errors for three determinations)

\begin{tabular}{lccccr}
\hline \hline & \multicolumn{2}{c}{ Fe (mg/kg) } & & & \multicolumn{2}{c}{$\begin{array}{c}\text { Specific activity } \\
\text { (counts/min per g) }\end{array}$} \\
\cline { 2 - 3 } \cline { 5 - 6 } Tissue & Mean & SE & & Mean & SE \\
\hline Breast & $48 \cdot 7$ & $0 \cdot 4$ & & 9425 & 142 \\
Leg & $24 \cdot 0$ & $0 \cdot 3$ & & 4248 & 99 \\
Liver & $190 \cdot 0$ & $3 \cdot 9$ & & 75369 & 8215 \\
\hline
\end{tabular}

RESULTS

The amount and distribution of $\mathrm{Fe}$ in pigeon tissues

The chemical and radioactive values are shown in Table 1 . The Fe content of pigeon breast muscle was higher than that of leg muscle. This is opposite to the finding with chicken, where leg Fe was higher than breast $\mathrm{Fe}$ (Bogunjoko et al. 1983). Liver Fe levels were, however, similar to those of chicken.

\section{Fractionation of the ${ }^{59} \mathrm{Fe}$-labelled compounds in pigeon tissues}

A very high percentage of the total $\mathrm{Fe}$ in pigeon tissues was extracted into the phosphate buffer at $\mathrm{pH} 7$, values being $85.3,82.7$ and 75.1 from the breast, leg and liver samples respectively. The concentrated soluble extract from these tissues, fractionated on Sephacryl S-300, separated into four radioactive peaks. The elution volumes of these ${ }^{59} \mathrm{Fe}$ peaks corresponded to the molecular weights of the Fe compounds ferritin, haemoglobin and myoglobin while the last peak mainly consisted of low-molecular-weight Fe complexes. The two intermediate peaks, haemoglobin and myoglobin, also absorbed strongly in the soret region as is characteristic of the haemoproteins.

The distribution of the Fe compounds estimated chemically and by radioactive analysis is shown in Table 2. While the insoluble Fe was between 14 and $25 \%$ of the total Fe from the tissues, the haem-Fe accounted for $79 \cdot 1 \%$ (breast) to $45 \%$ (liver) of total $\mathrm{Fe}$ and ferritin was between 5.8 and $26.5 \%$ (liver) of the total Fe. The total haem-Fe concentration in the tissues estimated by determining the non-haem-Fe content (Schricker et al. 1982) was lower (Table 3) than when estimated by the gel-filtration procedure.

In vitro solubility and effects of digestion of raw and cooked pigeon meat on ${ }^{59} \mathrm{Fe}$ solubility A simulated physiological digestion procedure gave values for ${ }^{59} \mathrm{Fe}$ solubility from raw and cooked pigeon meat as shown in Table 4. Cooking significantly $(P<0.01)$ decreased the percentage soluble ${ }^{59} \mathrm{Fe}$ after water extraction and at all stages of the in vitro digestion procedure for both meat samples. However, neutralization with $\mathrm{NaHCO}_{3}$ resulted in significantly reduced soluble ${ }^{59} \mathrm{Fe}$ which was no doubt due to the precipitation of the acid-denatured protein, haematin compounds and possibly Fe hydroxides. The soluble ${ }^{59} \mathrm{Fe}$ then increased with continued digestion, probably as a result of the enzymic breakdown of the precipitated haemoproteins and their resolubilization and also by the formation of low-molecular-weight soluble Fe chelates with the protein-digestion products of meat. This was demonstrated by analysis of the absorption spectra of the raw pigeon-meat supernatant fractions at the various stages of the in vitro digestion, which showed the stepwise loss of 
Table 2. Distribution $(\%$ total iron content) of Fe-containing compounds in pigeon (Columba L.) breast, leg and liver

(Values are means with their standard errors for four experiments)

\begin{tabular}{|c|c|c|c|c|c|c|c|c|c|c|c|c|}
\hline \multirow[b]{3}{*}{ Compound } & \multicolumn{4}{|c|}{ Breast } & \multicolumn{4}{|c|}{ Leg } & \multicolumn{4}{|c|}{ Liver } \\
\hline & \multicolumn{2}{|c|}{$\mathbf{R}$} & \multicolumn{2}{|l|}{$\mathrm{C}$} & \multicolumn{2}{|l|}{$\mathbf{R}$} & \multicolumn{2}{|c|}{$\mathrm{C}$} & \multicolumn{2}{|c|}{$\mathrm{R}$} & \multicolumn{2}{|l|}{$\mathrm{C}$} \\
\hline & Mean & $\mathrm{SE}$ & Mean & $\mathrm{SE}$ & Mean & SE & Mean & $\mathrm{SE}$ & Mean & $\mathrm{SE}$ & Mean & $\mathrm{SE}$ \\
\hline Ferritin & $5 \cdot 81$ & 0.73 & $4 \cdot 81$ & 0.75 & $10 \cdot 4$ & 0.98 & $8 \cdot 81$ & 1.7 & $26 \cdot 5$ & $2 \cdot 5$ & $23 \cdot 4$ & $2 \cdot 5$ \\
\hline Haemoglobin & $5 \cdot 48$ & $1 \cdot 18$ & $6 \cdot 20$ & $1 \cdot 1$ & $9 \cdot 22$ & 1.6 & $8 \cdot 96$ & 0.44 & $5 \cdot 48$ & $0 \cdot 70$ & $4 \cdot 57$ & $1 \cdot 0$ \\
\hline Myoglobin & $73 \cdot 6$ & 0.93 & $70 \cdot 6$ & 0.79 & $60 \cdot 4$ & $1 \cdot 8$ & 59.4 & $3 \cdot 4$ & $39 \cdot 6$ & $1 \cdot 1$ & $43 \cdot 3$ & 0.94 \\
\hline $\begin{array}{l}\text { Low-molecular-wt } \\
\text { Fe compounds }\end{array}$ & $3 \cdot 40$ & 0.42 & $4 \cdot 31$ & 0.43 & $2 \cdot 68$ & $0 \cdot 10$ & $5 \cdot 89$ & $0 \cdot 77$ & $3 \cdot 51$ & $0 \cdot 33$ & 2.91 & 0.56 \\
\hline $\begin{array}{l}\text { Haemosiderin } \\
\text { (insoluble Fe) }\end{array}$ & $14 \cdot 1$ & 0.57 & - & - & $17 \cdot 3$ & 0.76 & - & - & $24 \cdot 9$ & 0.34 & - & - \\
\hline
\end{tabular}

$\mathbf{R}$, obtained from relative ${ }^{59} \mathrm{Fe}$ activities; $\mathrm{C}$, determined by atomic absorption spectrophotometry.

Table 3. Non-haem-iron contents of pigeon (Columba L.) tissues using the method of Schricker et al. (1982) and haem-Fe obtained by difference

(Values are means with their standard errors for three determinations)

\begin{tabular}{|c|c|c|c|c|c|c|c|c|}
\hline \multirow[b]{2}{*}{ Tissue } & \multicolumn{2}{|c|}{ Non-haem-Fe (mg) } & \multicolumn{2}{|c|}{$\mathrm{Fe}(\%)$} & \multicolumn{2}{|c|}{ Haem-Fe (mg) } & \multicolumn{2}{|c|}{$\mathrm{Fe}(\%)$} \\
\hline & Mean & $\mathbf{S E}$ & Mean & SE & Mean & $\mathrm{SE}$ & Mean & $\mathrm{SE}$ \\
\hline Breast & 1.77 & 0.06 & $36 \cdot 3$ & $1 \cdot 2$ & $3 \cdot 10$ & 0.09 & $63 \cdot 7$ & $1 \cdot 8$ \\
\hline Leg & $0 \cdot 96$ & 0-04 & 39.9 & 1.8 & 1.44 & 0.02 & $60 \cdot 1$ & 0.69 \\
\hline Liver & $14 \cdot 1$ & $0-51$ & $74 \cdot 1$ & 2.7 & 4.91 & 0.58 & $25 \cdot 9$ & $3 \cdot 1$ \\
\hline
\end{tabular}

Table 4. Percentage ${ }^{59} \mathrm{Fe}$ solubility from raw and cooked pigeon (Columba L.) meat during simulated in vitro digestion

(Values are means with their standard errors for four determinations)

\begin{tabular}{|c|c|c|c|c|}
\hline \multirow[b]{3}{*}{ Digestion and extraction conditions } & \multicolumn{4}{|c|}{ Percentage soluble ${ }^{5 \theta} \mathrm{Fe}$ from } \\
\hline & \multicolumn{2}{|c|}{ Raw meat } & \multicolumn{2}{|c|}{ Cooked meat } \\
\hline & Mean & $\mathrm{SE}$ & Mean & SE \\
\hline Water, $4 \mathrm{~h}$ & $85 \cdot 9$ & 0.57 & $15 \cdot 4$ & $0 \cdot 38$ \\
\hline $\mathrm{HCl}+$ pepsin $(E C 3.4 .23 .1), 1.5 \mathrm{~h}$ & $88 \cdot 8$ & 0.55 & $21 \cdot 3$ & $3 \cdot 8$ \\
\hline $\mathrm{HCl}+$ pepsin $+\mathrm{NaHCO}_{3}$ (neutralization) & $37 \cdot 4$ & $2 \cdot 0$ & $12 \cdot 0$ & 0.05 \\
\hline \multicolumn{5}{|l|}{$\begin{array}{l}\mathrm{HCl}+\text { pepsin }+\mathrm{NaHCO}_{3}+\text { pancreatin-bile } \\
\text { extract digested for: }\end{array}$} \\
\hline $1 \mathrm{~h}$ & $54 \cdot 9$ & $3 \cdot 1$ & $25 \cdot 0$ & $0 \cdot 3$ \\
\hline $2 \mathrm{~h}$ & $60 \cdot 4$ & $1 \cdot 1$ & $26 \cdot 9$ & $0 \cdot 23$ \\
\hline $4 \mathrm{~h}$ & $64 \cdot 8$ & $0 \cdot 31$ & $27 \cdot 8$ & $3 \cdot 5$ \\
\hline
\end{tabular}


haem character (Fig. 1). The undigested extract exhibited a distinct soret peak at about $410 \mathrm{~nm}$, characteristic of the haemoproteins. On peptic digestion, the height of this peak was reduced. Ledward (1974) reported that this decreased soret absorption corresponds to decreased haematin-protein interaction and the formation of unbound haematin. On neutralization, the precipitation of the haemoproteins also led to the decreased height of the peak. However, continued pancreatic digestion led to the degradation of the precipitated haemoproteins and their resolubilization; hence the reason for the observed initial increase in the height of the soret peak. However, further degradation of the haem compounds due to digestion led to increasing loss of haematin character.

\section{In vivo absorption of raw and cooked pigeon meat and meat fractions}

The in vitro results of ${ }^{59} \mathrm{Fe}$ solubility were extended to in vivo ${ }^{59} \mathrm{Fe}$ absorption studies in Fe-replete rats that were intragastrically dosed with the different test meals. These absorption results are shown in Table 5. Cooking significantly $(P<0.01)$ reduced the absorption of pigeon whole meat ${ }^{59} \mathrm{Fe}$. Since the pigeon-meat soluble extract predominantly consisted of haemoproteins, it was not surprising that its absorption was also reduced by cooking. In a similar manner the heat applied during the fractionation of the haemoproteins from the other soluble Fe compounds was probably responsible for its low absorption. The absorption from cooked liver $(16.7 \%)$ was slightly higher than that from raw liver $(13.9 \%)$. This was, however, not statistically significant $(P>0.05)$. The absorption of ${ }^{59} \mathrm{Fe}$ from ferritin was very low, probably because it is a high-molecular-weight non-haem-Fe compound and was given in the absence of extra meat protein.

\section{DISCUSSION}

The concept of availability and the techniques being used to measure availability are the subjects of current debate. The term 'availability' has been used as synonymous with absorption (true and apparent), retention and utilization and incorporation into biologically active compounds. Most workers define availability as the proportion of a nutrient in a food which is absorbed and utilized (O'Dell, 1984) but others (Hallberg, 1986; Suttle, 1986) recognize availability as primarily the proportion of nutrient which is absorbed. The work described in this paper equates available $\mathrm{Fe}$ with absorbable $\mathrm{Fe}$ and while in some cases the short-term measurement of absorption (1-4 h) may agree with longer-term measurements of retention (Bogunjoko et al. 1983), in others, such as in the Fe-deficient rat, it does not.

The studies reported in the present paper are an extension of earlier studies by Bogunjoko et al. (1983) using rats, on Fe absorption and availability from chicken meat, a white meat, low in haemoproteins and total Fe. The total $\mathrm{Fe}$ in the pigeon meat used in the present study was significantly lower than the value of $19.4 \mathrm{mg} / \mathrm{kg}$ for roasted pigeon (Paul \& Southgate, 1978) but was three to four times greater than the chicken Fe level reported earlier. The high Fe level was associated with a very high haemoprotein concentration, well above the levels found in more commonly consumed red meats (Hazell, 1982). The variation in $\mathrm{Fe}$ and haemoprotein concentration between different animals and tissues is influenced by the level of activity (Lawrie, 1950), age or weight of the animal (Ledward \& Shorthouse, 1971), the Fe concentration in the diet (Macdoughall et al. 1973) and the extent of bleeding after slaughter.

The observation of increased non-haem-Fe concentration in pigeon tissues when estimated by the Schricker et al. (1982) method was similar to the results of Chen et al. (1984). The non-haem-Fe concentration of beef was found to be higher when determined by this method than by alternative methods of chelating non-haem-Fe with EDTA followed 


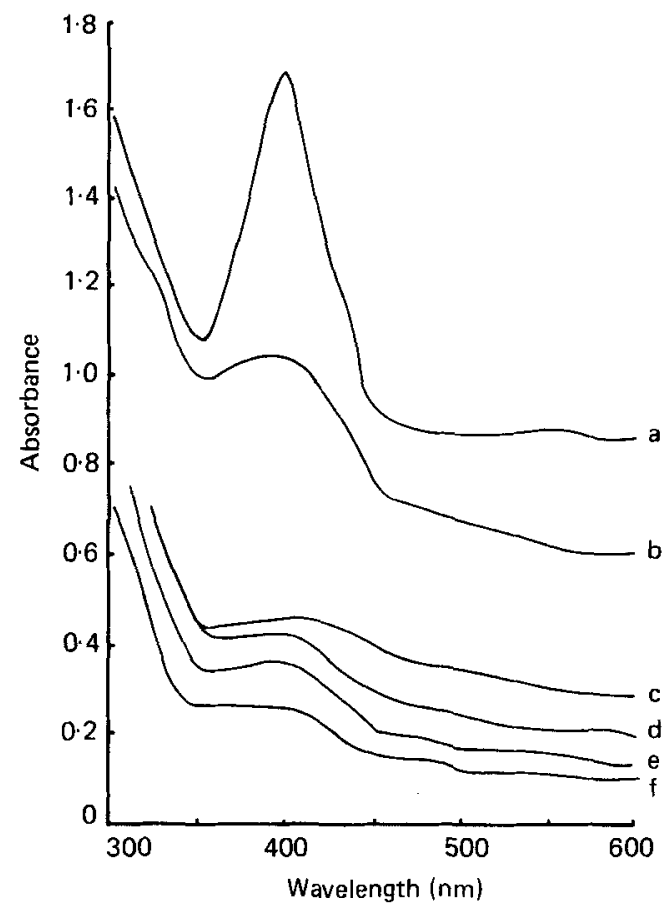

Fig. 1. Absorption spectra of supernatant fractions from raw pigeon (Columba L.) meat at various stages of in vitro digestion. (a) Scan of the undigested extract in distilled water at $\mathrm{pH} 7$; (b) scan of the supernatant fraction obtained on digestion of raw pigeon meat with pepsin $(E C$ 3.4.23.1) at $\mathrm{pH} 1.5$ for $1.5 \mathrm{~h}$; (c) scan of the supernatant obtained on digestion of raw pigeon meat with pepsin for $1.5 \mathrm{~h}$ followed by neutralization with sodium bicarbonate; (d) scan of $\mathrm{c}$ plus pancreatin-bile extract and digested for $1 \mathrm{~h}$ at $37^{\circ}$; (e) scan of $\mathrm{d}$ but digested for $2 \mathrm{~h}$; (f) scan of $\mathrm{d}$ but digested for $4 \mathrm{~h}$. All extracts were scanned from 300 to $600 \mathrm{~nm}$ with a Pye Unicam spectrophotometer.

Table 5. Percentage absorption of ${ }^{59} \mathrm{Fe}$ at $120 \mathrm{~min}$ by overnight-fasted Fe-replete rats given various test meals containing pigeon (Columba $L$.) meat, meat fractions and liver ( $40 \mu \mathrm{g} \mathrm{Fe} /$ test meal)

(Values are means with their standard errors for four rats unless otherwise indicated in parentheses)

\begin{tabular}{clcc} 
& & \multicolumn{2}{c}{ Percentage ${ }^{59} \mathrm{Fe}$ absorption } \\
\cline { 3 - 4 } Test meal no. & Type of test meal & Mean & SE \\
\hline 1 & Raw meat & 21.9 & $2.9(8)$ \\
2 & Cooked meat & 10.9 & $2.1(8)$ \\
3 & Raw soluble extract & 16.5 & 1.9 \\
4 & Cooked soluble extract & 8.98 & 2.4 \\
5 & Raw insoluble residue & 8.0 & 1.6 \\
6 & Cooked soluble residue & 10.5 & 2.4 \\
7 & Haemoproteins & 7.48 & 0.95 \\
8 & Ferritin & 3.13 & 0.70 \\
9 & Raw liver & 13.9 & 2.0 \\
10 & Cooked liver & 16.7 & 3.4 \\
\hline
\end{tabular}


by precipitation with TCA or acetone. It has, however, been suggested that the increase in non-haem-Fe concentration was due to the heat applied during the analysis which could lead to the release of $\mathrm{Fe}$ from the haem complex by oxidative cleavage of the porphyrin ring (Schricker et al. 1982).

During the digestion of meat, the haemoproteins are degraded to a series of lowermolecular-weight $\mathrm{Fe}$ compounds consisting of haematin and non-haematin complexes, which are very readily absorbed in vivo (Hazell et al. 1978). The extent of meat $\mathrm{Fe}$ degradation to low-molecular-weight non-haematin compounds could, however, be influenced by the meat types as well as the time of digestion.

In these studies test meals were formulated to provide equal Fe contents (i.e. $40 \mu \mathrm{g}$ ) but inevitably in doing so protein contents would have been markedly different as would amino acid concentrations. Although these were not measured the impact of the varying protein content and amino acid composition might well have been large as was shown by Bogunjoko et al. (1983) for the absorption of ferritin. It is not possible at the present time to know the contribution made by either protein or amino acid levels to the absorption of the total $\mathrm{Fe}$ from the various forms of Fe present in meat and further work is necessary to measure this.

In agreement with the results of Bogunjoko et al. (1983) for chicken, cooking was found to decrease significantly the in vitro ${ }^{59} \mathrm{Fe}$ solubility and in vivo absorption of ${ }^{59} \mathrm{Fe}$ from pigeon meat. Jacobs \& Greenman (1969) had earlier shown that the amount of soluble $\mathrm{Fe}$ was reduced after peptic digestion of cooked steak and bacon. The decreased solubility and absorption of $\mathrm{Fe}$, as a result of cooking, have been attributed to the denaturation and precipitation of meat haemoproteins which could not be significantly resolubilized by the acidic conditions occurring during peptic digestion. Since heat was also shown to increase non-haem-Fe concentration of pigeon meat, this decreased haem-Fe concentration could also negatively affect $\mathrm{Fe}$ absorption. In addition, the possibility of reduced protein digestibility on cooking (Bender, 1972) could lead to decreased peptides and amino acids released on early digestion which might reduce the formation of low-molecular-weight $\mathrm{Fe}$ chelates which are normally very well absorbed (Hazell et al. 1978).

In the raw (uncooked) state the haemoproteins, especially in the meat environment, are the highly available forms of all the Fe compounds in meat (Martinez-Torres \& Layrisse, 1971; Hazell et al. 1981). It would therefore be expected that the higher the concentration of haemoproteins in meat, the higher the solubility and absorption of its total Fe in the uncooked state. This was the observation in the present study, in which both in vitro ${ }^{59} \mathrm{Fe}$ solubility and in vivo ${ }^{59} \mathrm{Fe}$ absorption from pigeon meat (containing a significantly higher proportion of haemoproteins) were higher than that from raw chicken meat (Bogunjoko et al. 1983).

The increased Fe absorption from meats with high concentrations of haemoproteins does not, however, appear to show any simple mathematical relation between absorption and haemoprotein content. The higher protein:Fe value in raw meat as compared with the soluble extract may well favour improved Fe absorption by increasing the levels of low-molecular-weight non-haem-Fe compounds produced and thereby facilitating their absorption (Hazell et al. 1981).

The in vitro method used in the present work made use of sodium bicarbonate in the solid form for neutralization. The use of sodium bicarbonate in place of sodium hyroxide has advantages in being more physiological but some authors have criticized its use in the solid form because of the possible formation of local pockets of high $\mathrm{pH}$ during mixing and subsequent precipitation of $\mathrm{Fe}(\mathrm{OH})_{3}$.

In the present work large decreases in Fe solubility were seen both with raw and cooked meat (Table 4) but reproducibility was good and there was evidence for improved solubility 
of Fe during 'pancreatic' digestion. In all cases, however, the percentage Fe solubility consistently overestimated percentage Fe absorption in Fe-replete rats in whom the demand for $\mathrm{Fe}$ is low. There is, however, much better agreement quantitatively between in vitro $\mathrm{Fe}$ solubility and $\mathrm{Fe}$ absorption in Fe-deficient rats in whom the demand for $\mathrm{Fe}$ is much greater (R. J. Neale, unpublished results).

The high-molecular-weight Fe compounds (haemosiderin and ferritin) both showed low ${ }^{59} \mathrm{Fe}$ absorption, in agreement with earlier work. The extent of in vivo degradation of these proteins was not, however, measured and the form in which the Fe was absorbed from these compounds is not known. Addition of extra protein to ferritin does, however, result in marked improvement in $\mathrm{Fe}$ absorption (Bogunjoko et al. 1983). Cooking liver resulted in increased Fe absorption, an effect similar to that described by Naish et al. (1974) in rats. These workers explained the cooking effect on liver as being due to an increased concentration of low-molecular-weight Fe compounds which facilitated Fe absorption.

From this discussion it is clear that differences in the nature and composition of $\mathrm{Fe}$ compounds in meat and the effects of processing will affect overall meat-Fe absorption in vivo but the magnitude of the cooking effect would appear to be of greatest significance.

The Fe-absorption results in the present study should be considered in the light of recent publications showing varying levels of Fe retention in rats given whole wheat flour or basal diets containing varying Fe levels (Fairweather-Tait \& Wright, 1984). The Fe-replete rats used in the present study had been fed for a number of weeks on a stock diet containing $309 \mathrm{mg} \mathrm{Fe} / \mathrm{kg}$ before overnight fasting and dosing with the various meat test meals. At these high levels of dietary $\mathrm{Fe}$, rats retain much smaller doses of Fe from wheat than at lower levels of dietary $\mathrm{Fe}(7 \mathrm{mg} / \mathrm{kg})$. It is therefore conceivable that rats given lower dietary $\mathrm{Fe}$ levels would absorb and retain greater quantities of Fe from meat as they do with wheat. Further studies are in progress in this laboratory to investigate this effect.

The authors thank Mr C. Freeman for technical assistance and the Agricultural and Food Research Council and the Nigerian Government for financial support.

\section{REFERENCES}

Bender, A. E. (1972). Journal of Food Technology 7, 239-250.

Bjorn-Rasmussen, E. \& Hallberg, L. (1979). Nutrition \& Metabolism 23, 192-202.

Bogunjoko, F., Neale, R. J. \& Ledward, D. A. (1983). British Journal of Nutrition 50, 511-520.

Chen, C. C., Pearson, A. M., Gray, J. I., Fooladi, M. H. \& Ku, P. K. (1984). Journal of Food Science 49, $581-584$.

Clement, N., Torrance, J. D., Bothwell, T. H. \& Charlton, R. W. (1972). South African Journal of Medical Science 37, 7-14.

Conrad, M. E., Benjamin, B. J., Williams, H. L. \& Foy, A. L. (1967). Gastroenterology 53, 5-10.

Fairweather-Tait, S. J. \& Wright, A. J. A. (1984). British Journal of Nutrition 51, 185-191.

Food and Agriculture Organization/World Health Organization (1970). Requirements of Ascorbic Acid, Vitamin $D$, Vitamin $B_{12}$, Folate and Iron. Technical Report Series no. 452. Rome/Geneva: FAO/WHO.

Hallberg, L. (1986). Oral communication presented at the XIII International Congress of Nutrition, Brighton, 1985 [T. G. Taylor, editor]. London: John Libby.

Hazell, T. (1982). Journal of the Science of Food and Agriculture 33, 1049-1056.

Hazell, T., Ledward, D. A. \& Neale, R. J. (1978). British Journal of Nutrition 39, 631-638.

Hazell, T., Ledward, D. A., Neale, R. J. \& Root, I. C. (1981). Meat Science 5, 397-405.

Jacobs, A. \& Greenman, D. A. (1969). British Medical Journal 1, 673-676.

Lawrie, R. A. (1950). Journal of Agricultural Science 40, 356-366.

Ledward, D. A. (1974). Journal of Food Technology 9, 59-68.

Ledward, D. A. \& Shorthouse, W. R. (1971). Animal Production 13, 193-195.

MacDoughall, D. B., Bremner, I. \& Dalgarno, A. C. (1973). Journal of the Science of Food and Agriculture 24, 1255-1263.

Martinez-Torres, C. \& Layrisse, M. (1971). American Journal of Clinical Nutrition 24, 521-540.

Martinez-Torres, C., Renzi, M. \& Layrisse, M. (1976). Journal of Nutrition 106, 128-135.

Monsen, E. R., Hallberg, L., Layrisse, M., Hegsted, M., Coot, J. D., Mertz, W. \& Finch, C. A. (1978). American Journal of Clinical Nutrition 31, 134-141. 
Naish, R., Kimber, C. L. \& Deller, D. J. (1974). British Journal of Haematology 26, 459-469.

O’Dell, B. (1984). Nutrition Reviews 42, 301-308.

Paul, A. A. \& Southgate, D. A. T. (1978). McCance and Widdowson's The Composition of Foods, London: H.M. Stationery Office.

Schricker, B. R., Miller, D. D. \& Stouffer, J. R. (1982). Journal of Food Science 47, 740-742.

Suttle, N. F. (1986). Oral communication presented at the XIII International Congress of Nutrition, Brighton, 1985 [T. G. Taylor, editor]. London: John Libby. 